\title{
ANALISIS INDEKS PEMBANGUNAN MANUSIA, PRODUK DOMESTIK REGIONAL BRUTO SERTA PENGARUHNYA TERHADAP JUMLAH PENDUDUK MISKIN DI KOTA JAMBI PROVINSI JAMBI
}

\author{
Adi Putra ${ }^{1}$ \\ Dosen Tetap STIE Muhammaadiyah Jambi ${ }^{1}$ \\ putramm@,yahoo.co.id \\ Ratih Rosita ${ }^{2}$ \\ Dosen Tetap STIE Muhammaadiyah Jambi² \\ ratihrosita11@,gmail.com \\ Nani Suryani ${ }^{3}$ \\ Mahasiswa STIE Muhammaadiyah Jambi \\ nanisuryanijambi@,gmail.com
}

\begin{abstract}
This research is a quantitative descriptive study, taking the title "Analysis of the Influence of the Human Development Index and the Gross Regional Domestic Product on the Number of Poor Population in the City of Jambi". The research objective was to determine the development, as well as the influence of HDI and GRDP per capita on the number of poor people in Jambi City, Jambi Province. The tool used for analysis in this study is growth analysis and uses multiple regression analysis through $F$ test and t test. HDI and GRDP per capita From the results of the analysis, the study concluded that the value of HDI, GDP per capita and the number of poor people in Jambi City in this study period fluctuated. Whereas from the results of Regression analysis to see the influence together (simultaneously) there is a significant effect between the dependent variable or the dependent variable (Poor Population Number) of 0.005 and the correlation coefficient (R) of 0.806 or $80.6 \%$ shows the relationship between the independent variable with the dependent variable is very strong.
\end{abstract}

Keywords: Human Development Index, GRDP percapita, Poor Population

\section{Ringkasan}

Penelitian ini merupakan penelitian deskriptif kuantitatif, dengan mengambil judul Analisis Pengaruh Indeks Pembangunan Manusia Dan Produk Domestik Regional Bruto Terhadap Jumlah Penduduk Miskin Di Kota Jambi. Tujuan penelitian adalah untuk mengetahui perkembangan, serta pengaruh IPM dan PDRB perkapita terhadap Jumlah penduduk miskin di Kota Jambi Provinsi Jambi. Alat yang digunakan untuk analisis dalam penelitian ini adalah analisis pertumbuhan serta menggunakan analisis regresi berganda melalui uji $\mathrm{F}$ dan uji t. IPM dan PDRB perkapita Dari hasil analisis maka penelitian dapat disimpulkan nilai IPM, PDRB Perkapita dan Jumlah Penduduk Miskin Kota Jambi pada periode penelitian ini kondisinya berfluktuasi. Sedangkan dari hasil analisis Regresi untuk melihat Pengaruh secara bersama-sama (secara simultan) terdapat pengaruh yang signifikan antara variabel dependent atau variabel terikat (Jumlah Penduduk Miskin) sebesar 0,005 dan nilai koefisien korelasinya (R) sebesar 0,806 atau $80,6 \%$ menunjukan hubungan antara variabel bebas dengan variabel terikat sangat kuat.

Kata Kunci : Indeks Pembangunan Manusia, PDRB perkapita, Penduduk Miskin 


\section{PENDAHULUAN}

Pembangunan adalah suatu proses perubahan menuju ke arah yang lebih baik dan terus menerus serta untuk mewujudkan masyarakat Indonesia yang berkeadilan, berdaya saing, maju, dan sejahtera dalam wadah Negara Kesatuan Republik Indonesia. Konstitusi UUD 1945, secara eksplisit mengamanatkan bahwa tugas pokok pemerintah Republik Indonesia adalah "memajukan kesejahteraan umum, mencerdaskan kehidupan bangsa serta mewujudkan suatu keadilan sosial bagi seluruh rakyat Indonesia”. hal itu berarti, hidup bebas dari kemiskinan atau menikmati kehidupan yang layak merupakan hak asasi setiap warga negara. Pemerintah juga menyadari bahwa pembangunan nasional adalah salah satu upaya untuk mencapai tujuan masyarakat adil dan makmur.

Dalam pelaksanaan pemerintahan, pemerintah pusat maupun pemerintah daerah telah berupaya dalam melaksanakan berbagai kebijakan dan program-program penanggulangan kemiskinan namun masih jauh dari induk permasalahan, namun kebijakan dan program yang dilaksanakan saat ini masih belum menampakan hasil yang optimal. Masih terjadi kesenjangan antara rencana dengan pencapaian tujuan karena kebijakan dan program penanggulangan kemiskinan lebih berorientasi pada program sektoral. Oleh karena itu diperlukan suatu startegi penanggulangan kemiskinan yang terpadu, terintegrasi dan sinergi sehingga dapat menyelesaikan masalah secara tuntas terutama lingkaran kemiskinan (vicious cyrcle of proverty).

Kemiskinan merupakan masalah yang dihadapi oleh semua negara di dunia, terutama di negara sedang berkembang. Kemiskinan juga merupakan masalah kompleks di daerah yang dipengaruhi oleh beberapa faktor yang saling berkaitan, antara lain tingkat pendapatan masyarakat, pengangguran, kesehatan, pendidikan, akses terhadap barang dan jasa, lokasi, geografis, dan lokasi lingkungan. Badan Pusat Statistik (BPS) Kota Jambi mempublikasi bahwa pada tahun 2016 jumlah penduduk miskin di Kota jambi ada 51.610 jiwa, dengan nilai IPM Kota Jambi $76.14 \%$ sedangkan indikator tingkat kesejahteraan penduduk dalam bentuk PDRB perkapita sejumlah Rp 37.005.484.

Badan Pusat Statistik (2010), penetepan perhitungan garis kemiskinan dalam masyarakat adalah masyarakat yang berpenghasilan di bawah Rp 7.057 per orang per hari penetapan angka tersebut berasal dari perhitungan garis kemiskinan yang mencakup kebutuhan makanan dan non makanan. Untuk kebutuhan minimum makanan digunakan patokan 2.100 kilokalori per 
kapita per hari sedangkan untuk pengeluaran kebutuhan minimum non makanan meliputi pengeluaran untuk perumahan, pendidikan, dan kesehatan.

Definisi Pembangunan Manusia dan Pengukurannya UNDP (United Nation Development Programme) mendefinisikan pembangunan manusia sebagai suatu proses untuk memperluas pilihan-pilihan bagi penduduk. Dalam konsep tersebut penduduk ditempatkan sebagai tujuan akhir (the ultimate end) sedangkan upaya pembangunan dipandang sebagai sarana (principal means) untuk mencapai tujuan tersebu perlupeningkatan Produktivitas, Pemerataan, Berkesinambungan serta Pemberdayaan.

Pengukuran Indeks Pembangunan Manusia Dalam indeks pembangunan manusia terdapat tiga indikator yang digunakan untuk mengukur besar indeks pembangunan manusia suatu negara, sesuai denan Rumus umum yang digunakan untuk menghitung Indeks Pembangunan Manusia adalah sebagai berikut :

\section{$I P M=1 / 3\left(\right.$ Indeks $X_{1}+$ Indeks $X_{2}+$ Indeks $\left.X_{3}\right)$}

Dimana : $\mathrm{X}_{1}$ : Indeks harapan hidup, $\mathrm{X}_{2}$ : Indeks pendidikan, $\mathrm{X}_{3}$ : Indeks standar hidup layak, Sedangkan Konsep Pembangunan Manusia yang dikembangkan oleh erserikatan BangsaBangsa (PBB), menetapkan peringkat kinerja pembangunan manusia pada skala 0,0-100,0 dengan katagori sebagai berikut Tinggi ( > 80,0), Menengah Atas (66,0 - 79,9), Menengah Bawah (50,0 - 65,9), dan Rendah ( IPM < 50,0)

Sedangkan pengaruh PBRB Perkapita Terhadap Jumlah Penduduk Miskin, menurut Sadono Sukirno (2000), laju pertumbuhan ekonomi adalah kenaikan PDRB tanpa memandang apakah kenaikan itu lebih besar atau lebih kecil. Selanjutnya pembangunan ekonomi tidak semata-mata diukur berdasarkan pertumbuhan produk domestik regional bruto (PDRB) secara keseluruhan, tetapi harus memperhatikan sejauh mana distribusi pendapatan telah menyebar kelapisan masyarakat serta siapa yang telah menikmati hasil-hasilnya.

Oleh karenanya penulis tertarik untuk meneliti, bagaimana perkembangan Indeks Pembangunan Manusia, PDRB Perkapita dan Jumlah Penduduk Miskin di Kota Jambi serta Bagaimana pula pengaruh Indeks Pembangunan Manusia, dan PDRB Perkapita Terhadap Jumlah Penduduk Miskin di Kota Jambi.

\section{METODOLOGI}

Metode penelitian yang digunakan dalam penelitian ini adalah dengan menggunakan metode deskriptif dimana pada analisis yaitu metode yang menggambarkan keadaan yang sebenarnya berdasarkan apa yang tampak kemudian digunakan untuk memecahkan suatu 
masalah dengan cara mengumpulkan, menyusun, menganalisis, dan menginterpretasikan data sehingga dapat ditarik keimpulan. Selanjutnya Data yang digunakan dalam penelitian ini adalah data sekunder Menurut sugiyono (2004), data sekunder adalah data yang diperoleh dari bahan-bahan yang tersedia di buku-buku, majalah, jurnal, dan sumber lainnya yang secara tidak langsung berhubungan dengan penelitian. Sumber data yang digunakan dalam penelitian ini adalah di Badan Pusat Statistika (BPS) Kota Jambi.

Alat analisis data yang digunakan Untuk menjawab masalah pertama digunakan analisis Deskriptif kuantitatif dengan rumus perkembangan,sedangkan Untuk menjawab masalah kedu, menggunakan analisis regresi linier berganda yang telah ditransformasi kedalam bentuk logaritma dengan persamaan sebagai:

$$
\log Y=\beta_{0}+\log \beta_{1} X_{1}+\log \beta_{2} X_{2}+e
$$

Dimana :

$\log \mathrm{Y} \quad=$ Logaritma Jumlah Penduduk Miskin

$\beta_{0} \quad=$ Konstanta

$\log \beta_{1}, \beta_{2}, \beta 3=$ Logaritma Koefisien

$\log X_{1} \quad=$ Logaritma Indeks Pembangunan Manusia

$\log \mathrm{X}_{2} \quad=$ Logaritma PDRB per kapita

e $\quad=$ Standar Error

selanjutnya Persamaan diatas diestimasi dengan menggunakan metode Ordinary Least Square (OLS) dengan pengujian statistic melalui Uji t dan Uji F

\section{HASIL DAN PEMBAHASAN}

\section{Perkembangan Indeks Pembangunan Manusia di Kota Jambi}

Indeks Pembangunan Manusia (IPM) mengukur capaian pembangunan manusia berbasis sejumlah komponen dasar kualitas hidup. Secara keseluruhan angka IPM selama tiga belas tahun terakhir mengalami kenaikan dan perkembangan IPM dari tahun ke tahun cenderung berfluktuasi. Dari hasil penelitian terlihat bahwa pertumbuhan IPM Kota Jambi periode 2014 sd 2016 cenderung berfluktuasi dimana yang terendah terjadi pada tahun 2010 dengan index $4,7 \%$, sedangkan rata-rata perkembangan IPM sebesar 0,28 pertahun. Sedangkan Perkembangan PDRB Perkapita di Kota Jambi selama tiga belas tahun terakhir mengalami kenaikan dan perkembangan PDRB perkapita dari tahun ke tahun berfluktuasi yang terkecil 
pada tahun 2010 dengan perkembangan 4,22 persen dan yang tertinggi pada tahun 2005 sebesar 21,61 persen.

Perkembangan jumlah Penduduk Miskin di Kota Jambi selama tiga belas tahun terakhir juga berfluktuasi dimana pada data tahun 2004 jumlah penduduk miskin di Kota Jambi sebanyak 27.200 jiwa, kemudian mengalami penurunan menjadi 24.900 jiwa pada tahun 2005 . Namun pada tahun 2009 jumlah penduduk miskin dikota Jambi sebesar 50.700 jiwa naik menjadi 52.600 jiwa pada tahun 2010, akan tetapi pada tahun selanjutnya jumlah penduduk miskin dikota Jambi mengalami penurunan dari angka 54.300 jiwa di tahun 2012 menjadi 50.950 jiwa pada tahun 2014 kemudian pada tahun 2015 angka jumlah penduduk miskin mengalami kenaikan lagi mencapai angka sebesar 55.510 jiwa. Data terakhir pada tahun 2016 angka tersebut turun menjadi 51.610 jiwa.

\section{Hasil Analisis Regresi Indeks Pembangunan Manusia dan PDRB Perkapita Terhadap Jumlah Penduduk Miskin Kota Jambi}

Hasil analisis regresi linear berganda, variabel independent dalam penelitian ini yaitu indeks pembangunan manusia $\left(\mathrm{X}_{1}\right)$ dan PDRB perkapita $\left(\mathrm{X}_{2}\right)$. Sedangkan variabel dependent yaitu Jumlah Penduduk Miskin (Y).

Analisis statistik dalam penelitian ini menggunakan analisis regresi linier berganda. Dari hasil perhitungan dengan menggunakan bantuan SPSS Versi 23 didapatkan hasil seperti pada tabel 2 berikut sebagai berikut:

Tabel.1 Hasil Analisis Regresi

\begin{tabular}{|c|c|c|c|c|c|c|}
\hline \multirow{2}{*}{\multicolumn{2}{|c|}{ Model }} & \multicolumn{2}{|c|}{$\begin{array}{l}\text { Unstandardized } \\
\text { Coefficients }\end{array}$} & \multirow{2}{*}{$\begin{array}{l}\text { Standardized } \\
\text { Coefficients } \\
\text { Beta }\end{array}$} & \multirow[t]{2}{*}{$\mathrm{t}$} & \multirow[t]{2}{*}{ Sig. } \\
\hline & & $\mathrm{B}$ & Std. Error & & & \\
\hline 1 & (Constant) & 8.567 & 8.353 & & 1.026 & .329 \\
\hline & IPM & -4.816 & 4.622 & -.206 & -1.042 & .322 \\
\hline & PDRB Prkpt & .692 & .161 & .848 & 4.296 & .002 \\
\hline
\end{tabular}

a. Dependent Variable: Penddk Miskin

Berdasarkan hasil analisis regresi didapat persamaan sebagai berikut :

$\log \mathrm{Y}=8,567-4,816$ IPM + 0,692 PDRB Perkapita

Dari hasil analisis regresi terlihat bahwa apabila variabel IPM dan PDRB Perkapita dalam keadaan tetap maka jumlah penduduk miskin di Kota Jambi sebesar 8.567 jiwa. Selanjutnya, apabila terjadi peningkatan IPM sebesar 1\% maka Jumlah Penduduk Miskin Kota Jambi mengalami penurunan sebesar 4,816 jiwa, dilain sisi setiap terjadi kenaikan PDRB 
Perkapita sebesar Rp. 1,- maka Jumlah Penduduk Miskin Kota Jambi menurun penurunan sebesar 0,692 jiwa.

Hasil Uji f pengujian secara simultan didapatkan nilai Sig $0,005^{\mathrm{b}}$ ini menunjukan bahwa nilai significansinya lebih kecil pada tingkat keyakinan 95\% ( $\alpha=5 \%)$. yang menjelaskan bahwa semua variabel independent atau variabel bebas (Indeks Pembangunan Manusia dan PDRB Perkapita) secara bersama-sama berpengaruh terhadap variabel dependen.

Sedangkan dari hasil Uji t pengujian secara parsial untuk melihat pengaruh IPM terhadap Jumlah penduduk Miskin di Kota Jambi, dengan pada tingkat signifikasi $(\alpha=5 \%)$ terdapat nilai signifikan IPM sebesar 0,322. $>0.05$ hasil ini menjelaskan bahwa Index Pembangunan Manusia Kota Jambi tidak memperlihat berpengaruhnya yang significan terhadap jumlah penduduk miski di Kota Jambi. Hasil ini menjelaskan bukannya tidak ada pengaruh antara IPM terhadap jumlah penduduk miskin di Kota Jambi, tetapi pengaruh yang ada tersebut sangat kecil, kondisi tersebut sesuai dengan fakta lapangan yang ada dimana Kota Jambi merupakan ibu kota Provinsi Jambi serta pusat perdagangan. Di Kota Jambi semua lapisan masyarakat dapat berkegiatan dengan baik dan membuka dan mengembangkan usaha dalam bentuk apa saja baik yang diingikannya, termasuk sector-sektor informal yang tidak membutuhkan keahliaan yang tinggi. Pengembangan sector tersebut tidak mebutuhkan pendidkan yang tinggi namun dari pelaku usaha yang tidak sekolah pun dapat melaksanakannya, artinya jika semua masyarakat dapat berkegiatan dan penghasilan mereka meningkat maka tingkat IPM pengaruhnya sangat kecil terhadap jumlah penduduk Miskin di Kota Jambi.

Selanjutnya hasil dari Uji t pengujian secara parsial untuk melihat pengaruh PDRB Perkapita terhadap Jumlah penduduk Miskin di Kota Jambi, dengan pada tingkat signifikasi $(\alpha=5 \%)$ terdapat nilai signifikan IPM PDRB Perkapita dengan tingkat signifikansinya sebesar $0,002(0,002>0.05)$. Hasil ini menggambarkan adanya pengaruh yang PDRB Perkapita terhadap jumlah penduduk miskin di Kota Jambi pada periode tersebut.

Tabel.1 Koefisen Diterminasi variabel Dependent dan Independent

\begin{tabular}{l|r|r|r|r}
\hline Model & \multicolumn{1}{|c|}{$\mathrm{R}$} & R Square & Adjusted R Square & Std. Error of the Estimate \\
\hline 1 & $.806^{\mathrm{a}}$ & .650 & .580 & .10427 \\
\hline
\end{tabular}

a. Predictors: (Constant), PDRB Prkpt, IPM 
Berdasarkan hasil analisis didapat nilai koefisien determinasinya (R square) sebesar 0,650 yang menjelaskan bahwa seluruh variabel bebas Indeks Pembangunan Manusia dan PDRB Perkapita secara bersamaan dapat menerangkan variabel Jumlah Penduduk Miskin (Y) sebesar $65 \%$, sementara $35 \%$ dipengaruhi oleh variabel lain yang tidak termasuk dalam penelitian ini. Nilai koefisien korelasinya (R) diperoleh sebesar 0,806 atau 80,6\% artinya hubungan antara variabel bebas dengan variabel terikat sangat kuat.

Hasil penelitian ini juga menjelaskan apabila IPM mengalami peningkatan maka kemiskinan mengalami penurunan sehingga adanya hubungan antara peningkatan IPM dengan penurunan kemiskinan. Hal tersebut sesuai dengan teori ekonomi yang menyatakan bahwa apabila indeks pembangunan manusia meningkat, maka jumlah penduduk miskin akan mengalami menurun. Hal ini juga sesuai dengan teori yang dikemukakan oleh Tambunan (2001) pertumbuhan dan kemiskinan mempunyai korelasi yang sangat kuat, karena pada tahap awal proses pembangunan kemiskinan cenderung meningkat dan pada saat mendekati tahap akhir pembangunan jumlah orang-orang miskin berangsur-angsur berkurang. Selanjutnya Wiguna, (2013) dalam penelitiannya mengindikasikan bahwa apabila PDRB Perkapita meningkat maka penduduk di wilayah tersebut sejahtera karena tingkat kemsikinan pun akan berkurang.

\section{KESIMPULAN}

Dari hasil penelitian ini maka dapat ditarik kesimpulan yaitu nilai IPM, PDRB Perkapita dan Jumlah Penduduk Miskin Kota Jambi pada periode penelitian ini kondisinya berfluktuasi. Sedangkan dari hasil analisis Regresi untuk melihat Pengaruh secara bersama-sama (secara simultan) terdapat pengaruh yang signifikan antara variabel dependent atau variabel terikat (Jumlah Penduduk Miskin) sebesar 0,005 dan nilai koefisien korelasinya (R) sebesar 0,806 atau $80,6 \%$ menunjukan hubungan antara variabel bebas dengan variabel terikat sangat kuat.

\section{DAFTAR PUSTAKA}

Arsyad, L. 2010. Ekonomi Pembangunan. Edisi Kelima. STIM YKPN, Yogyakarta.

Badan Pusat Statistik Kota Jambi. (2016). Statistik Daerah Kota Jambi Tahun 2015.Katalog :1102001.3402.

Badan Pusat Statistik Kota Jambi. (2017). Statistik Daerah Kota Jambi Tahun 2015.Katalog :1102001.3402.070.070 
Cholili, F.M. 2014. Analisis Pengaruh Pengangguran, PDRB, dan IPM terhadap Jumlah penduduk Miskin (studi kasus: 33 Privinsi di Indonesia). Universitas Bramawijaya, Malang.

Dewi, Novita. Pengaruh Kemiskinan dan Pertumbuhan Ekonomi Terhadap Indeks Pembangunan Manusia di Provinsi Riau.

Eliza., 2012. Faktor-Faktor Yang Mempengaruhi Jumlah Penduduk Miskin di Kota Jambi.

Fadillah, Nurul, dkk.2013. Analisis Pengaruh Pendapatan Per Kapita, Tingkat Pengangguran, Pertumbuhan Penduduk Terhadap Kemiskinan di Kota Jawa Tengah.

Ghozali, Imam. 2012. Aplikasi Analisis Multivariate dengan Program IBM SPSS 20. Semarang: Badan Penerbit - Universitas Diponegoro.

Junaidi, dkk. 2014. Determinan Kemiskinan Rumah Tangga Di Provinsi Jambi. FEB Unja.

Napitupulu, A.S. 2007. Pengaruh Indikator Komposit IPM Terhadap Penurunan Jumlah Penduduk Miskin Di Sumatera Utara. Sumatera Utara: Universitas Sumatera Utara.

Soleh, A. (2018). Analisis dan Strategi Pengentasan Kemiskinan Di Provinsi Jambi. EKSIS: Jurnal Ilmiah Ekonomi dan Bisnis, 9(1), 79-90.

Sugiyono. 2014. Metode Penelitian Pendidikan Pendekatan Kuantitatif, Kualitatif Dan R\&D. Bandung:Alfabeta.

Sukirno, Sadono. 2002. Pengantar Teori Ekonomi Mikro. Pt. Raja Grafindo Persada. Jakarta.

Tambunan, Tulus. 2001. Perekonomian Indonesia : Teori Dan Temuan Empiris. Cetakan Kedua

Todaro. MP. 2003. Ekonomi Pembangunan Di Negara Dunia Ketiga. Ghalia Indonesia. Jakarta.

Wiguna, Van Indra. 2013. "Analisis Pengaruh PDRB, Pendidikan dan Pengangguran Terhadap Kemiskinan di Provinsi Jawa Tengah Tahun 2005-2010”. Malang: Universitas Brawijaya Malang.

World Bank. 2004. Definisi Kemiskinan. http://www.worldbank.org(online). Diakses tanggal 12 Juni 2016. 